\title{
TAMARIX DUEZENLII (TAMARICACEAE) - A SPECIES NEW TO SCIENCE FROM SOUTHERN TURKEY
}

\author{
HALIL ÇAKAN $^{1}$, JERZY ZIELIŃSKI ${ }^{2}$ \\ ${ }^{1}$ Çukurova University, Department of Biology \\ Balcali, 01330, Adana, Turkey \\ e-mail: hcakan@mail.cu.edu.tr \\ 2 Polish Academy of Sciences, Institute of Dendrology \\ Parkowa 5, 62-035 Kórnik, Poland \\ e-mail: jeziel@rose.man.poznan.pl
}

(Received: August 18, 2003. Accepted: September 3, 2003)

\begin{abstract}
Tamarix duezenlii, belonging to Tamarix L. ser. Leptostachyae (Bunge) Baum, is described as a species new to science. It is related to T. hispida Willd. and T. arborea (Sieber ex Ehrenb.) Bunge. From the former species it differs by its dense inflorescences, white petals and paralophic disc; from the latter by a shrubby habit, elliptic petals and calyx abruptly narrowed at the base. The species occurs in saline areas of the Çukurova Deltas at the mouths of the Seyhan and Ceyhan rivers in southern Turkey.
\end{abstract}

KEY WORDS: East-Mediterranean region, southern Turkey, Çukurova Deltas, Tamarix duezenlii, Tamaricaceae, new species.

A species of Tamarix L., new to science, was found by the first author (H.Ç.) in 2000 during field studies on the vegetation and flora of the Çukurova Deltas in the south of Adana province in southern Turkey. The area, formed by the estuaries of the Seyhan and Ceyhan rivers at the southern coast of Turkey, is one of the most important wetlands in the eastern Mediterranean region, and included in the list of so-called RAMSAR sites (GDEP 1998). Its native flora comprises some 560 taxa, including 63 rare or threatened species; 31 taxa are endemic to the area (Çakan et al. 2002). The saline places are covered with the unique halophilous vegetation formed together with other plants by numerous tamarisks. Besides the new species to be described later, the genus Tamarix is represented in the area by $T$. hampeana Boiss. (Çakan 1369, vouchers at ADA and KOR) T. tetrandra Pall., T. ramosissima Ledeb. (=T. smyrnensis Bunge), T. tetragyna Ehrenb. \& Heldr. (Zieliński 1994; Çakan \& al. 1995). Most of the natural places in the Çukurova Deltas, including habitats of $T$. duezenlii, have been more or less altered by anthropogenic activities, e.g., agriculture, tourism, construction of new roads and settlements, cutting for fuel, etc. $T$. duezenlii is now a rare and threatened species and only 40-50 scattered shrubs growing in two isolated groups have been observed.

The new species honours Dr Atabay Düzenli, professor of botany at Çukurova University, Adana, Turkey.
Tamarix duezenlii Çakan \& Zieliński sp. nov. Figs 1-2. Frutex usque 2-2.5 altus. Rami rubro-brunnei. Ramuli annotini dense papillosi usque puberuli. Folia $1.2-2 \mathrm{~mm}$ longa, sessilia, ovato-lanceolata raro ovata, basi rotundata vel late cuneata, glaucescentia, dense papillosa. Inflorescentiae aestivales e racemis compositae. Racemi 3-7 cm longi, 4-5 mm lati. Axis dense papillosus usque puberulus. Bractae 2.5-2.7 mm longae, ovatae usque ellipticae, longe acuminatae, papillosae, margine minute denticulatae, calyces excendentes. Calyx $1.5 \mathrm{~mm}$ longus, papillosus. Sepala c. $1 \mathrm{~mm}$ longa, papillosa, margine brevissime denticulata. Petala $2 \mathrm{~mm}$ longa, elliptica usque oblongo-elliptica. Stamina antesepalina. Filamentorum insertio peridiscalis. Discus paralophus.

Shrub 2-2.5 m tall. Stems reddish-brown. Annual branchlets densely papillose to minutely pilose. Leaves scaly, those of ultimate twigs 1.2-2 mm long, ovate-lanceolate, rarely ovate, slightly auriculate and rounded to broadly cuneate at the base, glandular-pitted, glaucous, densely papillose, on the main leading twigs longer, truncate or subcordate at base. Inflorescence aestival on current year's branchlets, racemose. Racemes 3-7 cm long, 4-5 mm broad. Inflorescence axis papillose to puberulent. Bracts ovate to elliptic, narrowed into a long cusp, papillose, minutely denticulate at margin, exceeding sepals. Calyx 


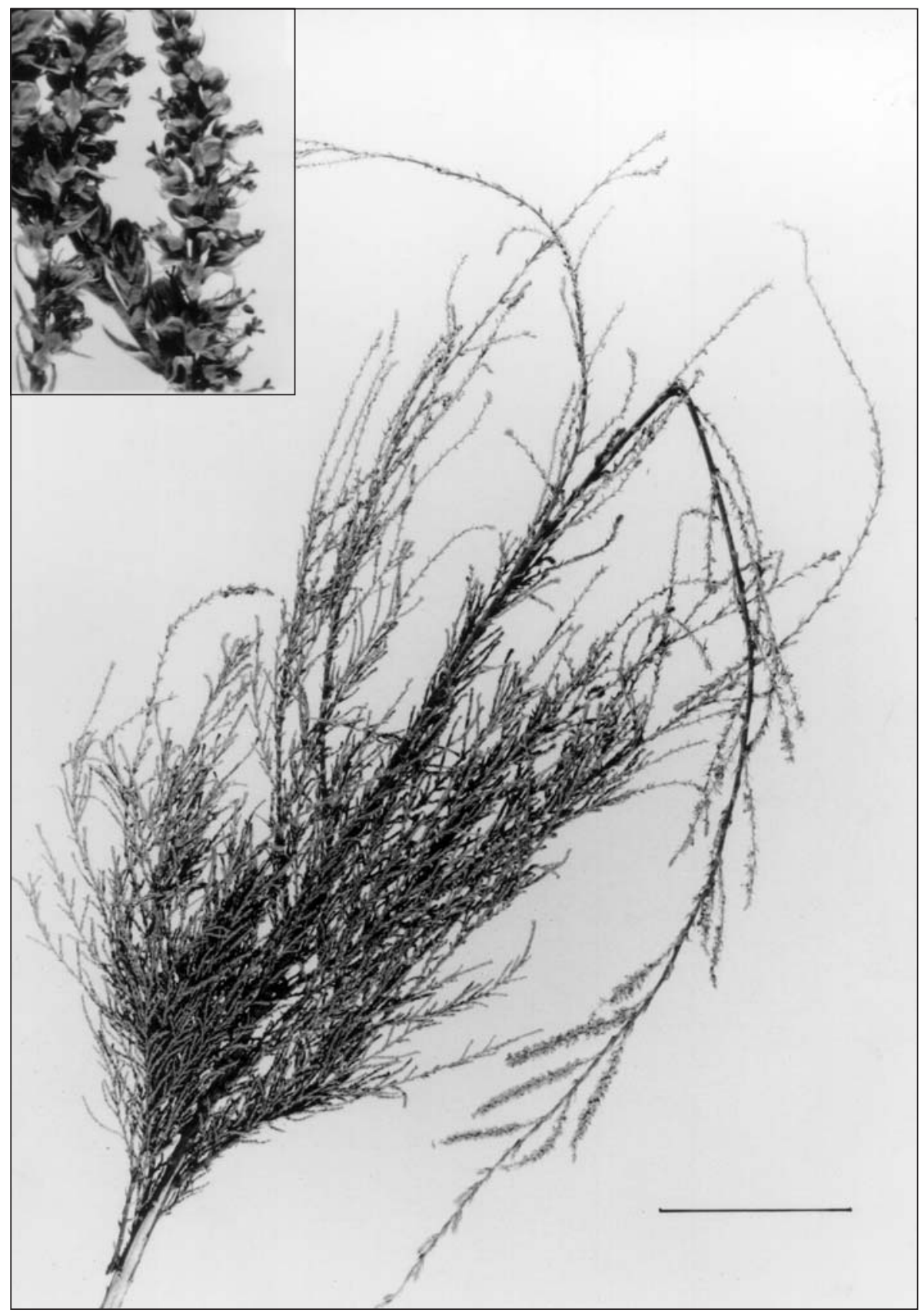

Fig. 1. Isotype of Tamarix duezenlii Çakan \& Zieliński (Çakan 1167, KOR); scale bar = $5 \mathrm{~cm}$. Inset: fragment of inflorescence. Scale bar $=5 \mathrm{~cm}$. Photo by M. Dziurla. abruptly attenuate at the base. Sepals $1 \mathrm{~mm}$ long, ovate to ovate-trullate, obtuse or acute, densely papillose as in bracts, the outer ones slightly keeled. Petals $2 \mathrm{~mm}$ long, elliptic to oblong-elliptic, white, pinkish in bud, caducous. Stamens antisepalous; filaments peridiscal; anthers pink. Disc paralophic.

Type: TURKEY C5 Adana: Çukurova Delta, Tuzla district, Tuzla lagoon near Seyhan river, edge of saline lagoon, near sea level, 23 August 2000, H. Çakan 1167 (Herbarium of Çukurova University, Adana, ADA, holotype); KOR (isotype).

Tamarix duezenlii belongs to series Leptostachyae (Bunge) Baum (Baum 1978) and is closely related to $T$. hispida Willd. and T. arborea (Sieber ex Ehrenb.) Bunge. The former species differs from $T$. duezenlii by its lax inflorescences, dark pink flowers, and synlophic disc, while $T$. arborea is a tree bearing flowers with obovate petals and calyx gradually attenuating at base into the pedicel.

\section{ACKNOWLEDGEMENTS}

The authors are much indebted to M. Sc D. Tomaszewski and Mr M. Dziurla for preparing photographs of the new species and to Dr Kit Tan, Copenhagen, for linguistic improvement and correction of this article.

\section{LITERATURE CITED}

BAUM B. 1978. The genus Tamarix. The Israel Academy of Sciences and Humanities, Jerusalem.

ÇAKAN H., DÜZENLI A., KARAÖMERLIOGLU D. 2002. Vegetation of Çukurova Deltas (Yumurtalýk Lagoon, Akyatan, Aðyatan and Tuz lake) in Mediterranean, Turkey. Unpublished Report to TUBITTAK. 

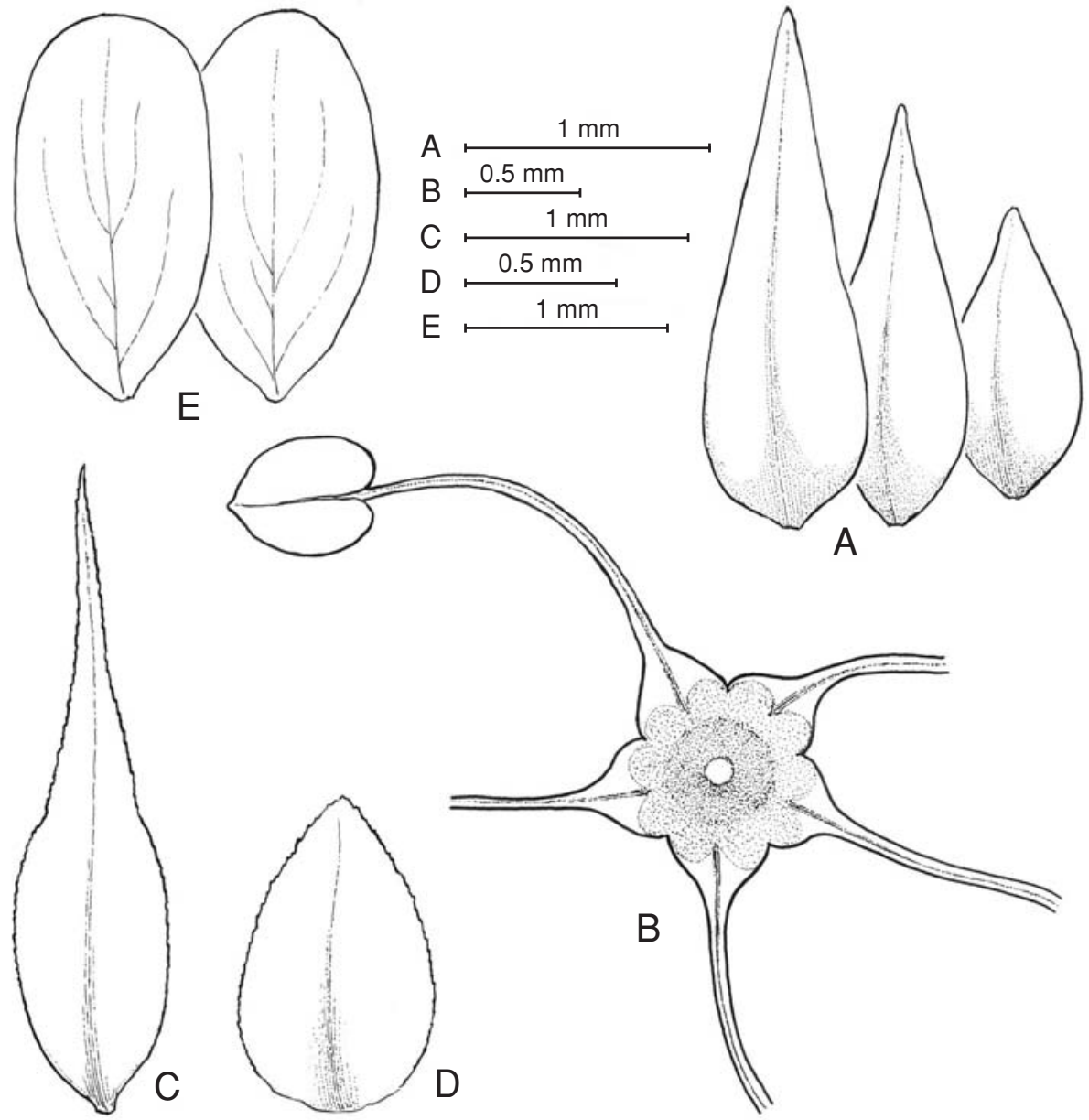

A
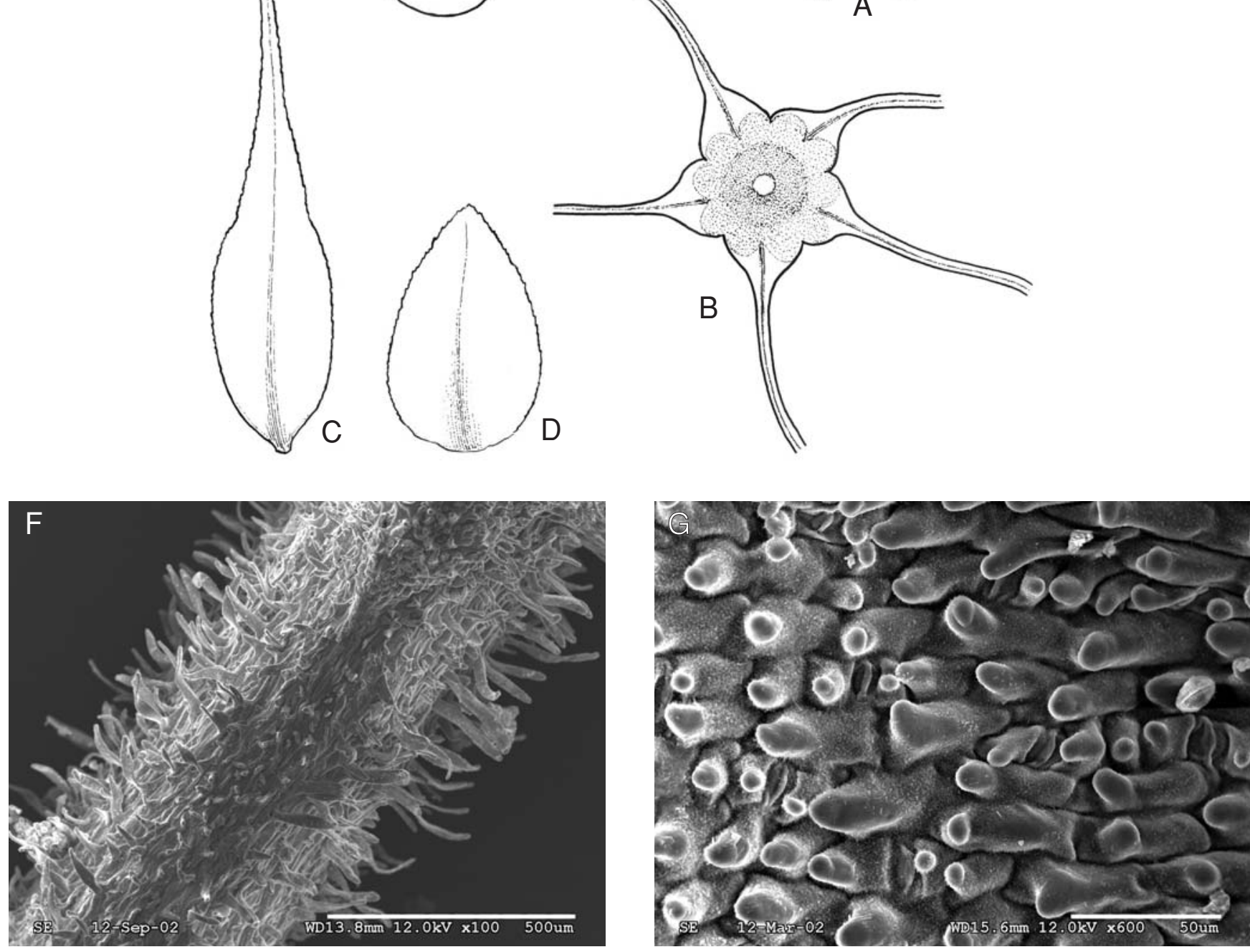

Fig. 2. Tamarix duezenlii: A - leaves, B - androecium, C - bract, D - sepal, E - petals, F - fragment of flowering stem, $\mathrm{G}$ - sepal epidermis (all from isotype, Çakan 1167, KOR). SEM photo by D. Tomaszewski.

ÇAKAN H., DÜZENLI A., TÜRKMEN N., ZIELIŃSKI J. 1995. Tamarix tetragyna Ehrenb. \& Heldr. (Tamaricaceae) in Turkey. Karaca Arbor. Magazine 3, 1: 1-5.

GDEP (General Directorate of Environmental Protection) 1998. The Akyatan Lagoon. Republic of Turkey. Ministry of Environment. Wetland Section, January 1998.
ZIELIŃSKI J. 1994. Tamarix L. In: K. Browicz. Chorology of trees and shrubs in south-west Asia and adjacent regions 10: 30-34. Bogucki Wydawnictwo Naukowe, Poznań. 